\title{
Faktor-Faktor yang Berhubungan dengan Kualitas Hidup Pasien Kanker Payudara di RSUD Raden Mattaher Jambi
}

\author{
Debbie Nomiko \\ Jurusan Keperawatan Poltekkes Kemenkes Jambi \\ Jln Dr. Tazar Buluran Kenali No 05 Jambi \\ Correspondence email: debbie_nomiko@yahoo.com
}

\begin{abstract}
Abstrak. Kanker payudara adalah penyakit yang terjadi karena pertumbuhan berlebihan atau perkembangan tidak terkontrol dari sel-sel atau jaringan payudara. Kualitas hidup merupakan tujuan penting dalam pengobatan kanker,dan kekhawatiran akan kondisi fisik, psikologis, gangguan citra tubuh. Tujuan penelitian ini untuk mengetahui faktor-faktor yang berhubungan kualitas hidup pasien kanker payudara di RSUD Raden Mattaher Jambi Tahun 2019. Penelitian menggunakan desain penelitian deskriptif korelatif dengan pendekatan cross sectional. Populasi penelitian adalah pasien kanker payudara yang berobat di RSUD Raden Mattaher Jambi. Pengambilan sampel dilakukan secara kuota sampling. Instrumen pengumpulan data menggunakan kuisioner data karakteristik responden, mekanisme koping, dan kuisioner kualitas hidup dengan menggunakan format EORTC-QLQ 30. Data dianalisis secara univariat dan bivariat dengan uji Kai- Kuadrat (CI 95\%). Hasil penelitian diperoleh rata-rata usia responden adalah 51,8 tahun, mayoritas berpendidikan SD dan SMA dengan proporsi 35,7\%, dan sebagian besar tidak bekerja sebanyak 35 orang $(62,5 \%)$. Hasil analisis bivariat bahwa terdapat hubungan antara lama kanker dan mekanisme koping dengan kualitas hidup pasien kanker payudara di RSUD Raden Mattaher Jambi. Diharapkan rumah sakit pihak rumah sakit dapat memfasilitasi kegiatan interaksi pasien kanker melalui pembentukan kelompok bagi penderita kanker sehingga mereka dapat sharing pengalaman dan informasi dalam hal peningkatan kualitas hidup. Bagi penelitian keperawatan diharapkan penelitian ini dapat menjadi data dasar dalam melaksanakan penelitian selanjutnya.
\end{abstract}

Kata Kunci: Kualitas hidup; Mekanisme Koping; Karakteristik Demografi; Kanker Payudara

Abstract. Breast cancer is a disease that occurs due to excessive growth or uncontrolled development of cells or breast tissue. Quality of life is an important goal in the treatment of cancer, and concerns about physical, psychological, body image disorders. The purpose of this study is to find out the factors related to the quality of life of breast cancer patients at Raden Mattaher Jambi Hospital in 2019. Research uses a coelative descriptive research design with a cross sectional approach. The research population is breast cancer patients who are treating at Raden Mattaher Jambi Hospital. Sampling is done on a sampling quota. Data collection instruments use the respondent's characteristic data questionnaire, coping mechanism, and quality of life questionnaire using the EORTC-QLQ 30 format. The data was analyzed univariate and bivariate with the Kai-Squared test (CI 95\%). The results of the study obtained the average age of respondents was 51.8 years, the majority were elementary and high school educated with a proportion of $35.7 \%$, and most did not work as many as 35 people $(62.5 \%)$. The results of bivariate analysis that there is a relationship between the length of the cancer and the mechanism of coffee and the quality of life of breast cancer patients in Raden Mattaher Jambi Hospital. It is hoped that hospitals can facilitate the interaction activities of cancer patients through the formation of groups for cancer patients so that they can share experiences and information in terms of improving quality of life. For nursing research, it is hoped that this research can be the basic data in carrying out the next research.

Keywords: Quality of life; Coping Mechanism; Demographic Characteristics; Breast Cancer

\section{PENDAHULUAN}

Penyakit kanker merupakan salah satu penyebab kematian utama di seluruh dunia. Saat ini salah satu jenis penyakit kanker yaitu kanker payudara, menjadi salah satu jenis kanker yang sangat menakutkan bagi perempuan di seluruh dunia termasuk Indonesia. Kanker payudara adalah penyakit yang terjadi karena pertumbuhan berlebihan atau perkembangan tidak terkontrol dari sel-sel atau jaringan payudara. Kanker payudara merupakan salah satu jenis kanker yang mempunyai prevalensi cukup tinggi. Kanker payudara dapat terjadi pada pria maupun wanita, hanya saja prevalensi pada wanita jauh lebih tinggi.

Kanker payudara merupakan penyumbang kematian sebesar $6,6 \%$ dari seluruh kematian akibat kanker di dunia,dengan jumlah kasus sebesar 11,6\% dari seluruh jenis kanker, sedangkan insiden kanker payudara pada perempuan di Indonesia sebesar 11,3\%. (International Agency for Research on Cancer (2018)

Secara nasional prevalensi penyakit kanker pada penduduk semua umur di Indonesia tahun 2013 sebesar $1,4 \%$ atau diperkirakan sekitar 347.792 orang. DI Yogyakarta memiliki prevalensi tertinggi untuk penyakit kanker, yaitu sebesar $4,1 \%$, sedangkan prevalensi kanker payudara untuk propinsi Jambi sebesar $1,5 \%$ atau diperkirakan sekitar 4.995 penduduk (Infodatin, 2016)

Perubahan fisik yang menyertai penyakit dan proses dan pengobatan merupakan salah satu masalah psikologis pada penderita kanker payudara. Kondisi ini dapat mempengaruhi konsep diri penderita kanker payudara . Seseorang yang mendapatkan diagnosa kanker secara umum penderita akan merasa kaget,shock 
dan bahkan mengalami distress emosional yang menetap. (Kamelia, 2013)

Mekanisme koping adalah usaha yang digunakan seseorang untuk mengurangi stressor dari masalah yang dihadapi, usaha ini meliputi usaha pertahanan ego yang digunakan untuk mempertahankan ego diri (Stuart, 2013). Sumber koping dan berbagai dukungan sangat diperlukan untuk mengatasi stress pada pasien kanker payudara. Berdasarkan hasil penelitan (Johansson et al, 2013) bahwa karakteristik individu juga turut mempengaruhi stress yang dialami oleh pasien kanker payudara antara lain umur, pendidikan, status perkawinan, agama, pekerjaan, stadium kanker.

Strategi koping yang digunakan sesuai dapat mempengaruhi emosi bahkan pikiran seseorang sehingga dapat mengurangi stresor yang dihadapi. Strategi ini dapat menghasilkan kualitas hidup yang lebih baik dan menghasilkan tindakan yang positif. Sebaliknya apabila strategi koping yang digunakan tidak sesuai dapat menghasilkan kualitas hidup yang buruk dan indivdu tersebut dapat mengalami distress emosional yang berat (Hae-chung, 2008)

Kualitas hidup merupakan tujuan penting dalam pengobatan kanker,dan kekhawatiran akan kondisi fisik, psikologis, gangguan citra tubuh serta gejala-gejala yang dapat menimbulkan distress emosional perlu segera diantisipasi untuk meningkatkan kualitas hidup pasien kanker. Meningkatkan kualitas hidup pasien kanker selama pengobatan akan meningkatkan kepatuhan mereka dalam perawatan dan pengobatan serta memberikan mereka kekuatan untuk mengatasi berbagai gejala atau keluhan yang dialami pasien kanker .(Bayram, Durna, \& Akin, 2014)

Berdasarkan data dari RSUD Raden Mattaher Jambi, pasien yang menderita kanker payudara yang terdata pada tahun 2017 sebanyak 244 orang, tahun 2018 pasien menderita kanker payudara sebanyak 226 orang. (RSUD Raden Mattaher Jambi, 2019).

Belum begitu banyak tentang penelitian tentang mekanisme koping dan kaitannya dengan kualitas hidup sebelumnya yang diteliti di RSUD Raden Mattaher Jambi, serta dengan didasari untuk mengetahui hubungan karakteristik demografi dan mekanisme koping dalam kaitannya dengan kualitas hidup yang dapat membantu meningkatkan kuantitas dan kualitas hidup pasien kanker payudara yang menjalani pengobatan, maka peneliti tertarik untuk meneliti hal tersebut dengan judul : Faktor-faktor yang berhubungan dengan Kualitas Hidup Pasien Kanker Payudara di RSUD Raden Mattaher Jambi tahun 2019

\section{METODE}

Jenis penelitian ini merupakan jenis penelitian kuantitatif dengan menggunakan desain penelitian crossectional yang bertujuan untuk menggambarkan hubungan antara variabel independen (mekanisme koping, karakteristik demografi, dan lama kanker) dengan variabel dependen (kualitas hidup) pasien kanker payudara.

Penelitian dilaksanakan di RSUD Raden Mattaher Jambi. Populasi dalam penelitian ini adalah seluruh pasien kanker payudara di RSUD Raden Mattaher Jambi sebanyak 126 orang penderita kanker payudara pada tahun 2018. Jumlah sampel dalam penelitian ini sebanyak 56 orang yang menjalani pengobatan di RSUD Raden Mattaher Jambi pada bulan Oktober- November 2019 . Metode Pengambilan sampel secara simple random sampling

Pengumpulan data dilaksanakan dari tanggal 22 Oktober - 15 November 2019 Pengumpulan data menggunakan menggunakan data kuisioner berisi pernyataan tentang data demografik responden dan pertanyaan tentang mekanisme koping pasien. Sedangkan pengumpulan data untuk variabel kualitas hidup menggunakan Breast Quality of Life (Kuisioner EORTC-QLQ-C30, yang terdiri dari 30 pertanyaan yang mengukur berbagai aspek kualitas hidup yang diklasifikasikan menjadi 15 dimensi termasuk lima sub skla fungsional (fisik, peran, kognitif, emosional dan social), tiga subskala gejala (kelelahan, nyeri, mual dan muntah), satu sub skala kesehatan umum dan enam item gejala tunggal yang menangani berbagai gejala kesehatan dan dampak keuangan yang dirasakan pasien. Semua item menggunakan skala likert empat poin, kecuali untuk kesehatan umum yang menggunakan skala tujuh poin

\section{HASIL DAN PEMBAHASAN Karakteristik Demografi Responden}

Tabel 1. Distribusi Responden menurut Karakteristik Demografi berdasarkan Usia Responden di RSUD Raden Mattaher Jambi tahun 2019

\begin{tabular}{|c|c|c|c|c|c|c|c|}
\hline No & Yariabel & Mean + SD & Med & Min & Mak & $\mathbf{N}$ & $\%$ \\
\hline 1 & Usia & $51,18+8,23$ & 52,0 & 35 & 67 & 56 & 100 \\
\hline \multirow[t]{6}{*}{2} & Pendidikan & & & & & & \\
\hline & Tidal Sekolah & & & & & 1 & 1,8 \\
\hline & SD & & & & & 20 & 35,7 \\
\hline & SMP & & & & & 5 & 8,9 \\
\hline & SMA & & & & & 20 & 35,7 \\
\hline & PT & & & & & 10 & 17,9 \\
\hline \multirow[t]{3}{*}{3} & Rendidikan & & & & & & \\
\hline & Rendah & & & & & 46 & 82,1 \\
\hline & Tinggi & & & & & 10 & 17,9 \\
\hline \multirow[t]{7}{*}{4} & Rekerjaan & & & & & & \\
\hline & PNS/Rolti & & & & & 5 & 8,9 \\
\hline & Regawai & & & & & 3 & 5,4 \\
\hline & Swasta/BUMN & & & & & 5 & 8,9 \\
\hline & Wirausaha & & & & & 8 & 18,3 \\
\hline & Retani/Delayan & & & & & 35 & 62,5 \\
\hline & Lain/lain & & & & & & \\
\hline \multirow[t]{3}{*}{5} & Pekerjaan & & & & & & \\
\hline & Bekerja & & & & & 21 & 37,5 \\
\hline & Tidak bekeria & & & & & 35 & 62,5 \\
\hline
\end{tabular}

Tabel 1 menunjukkan bahwa karakteristik demografi responden kanker payudara adalah 51,18 \pm 8,229 dengan usia tertua 67 tahun dan termuda 35 tahun, dan proporsi responden berdasarkan katagori usia responden sebagian besar berada di atas usia 45 tahun sebanyak 40 orang $(71,4 \%)$. Hal ini tidak jauh berbeda 
dengan penelitian (Purkayastha, 2017) yang mengatakan bahwa usia rata-rata pasien kanker payudara adalah 47,6 tahun (kisaran 30-75 tahun). Sedangkan penelitian Angraini, D dkk (2018) menunjukkan rerata umur responden kanker payudara adalah 52 tahun, Hasil penelitian ini berbeda dengan penelitian yang dilakukan (Anggorowati, 2013) yang mendapatkan hasil distribusi kelompok umur terbanyak pasien kanker payudara pada usia $<42$ tahun.

\section{Lama Kanker, Mekanisme Koping dan Kualitas Hidup Responden}

Tabel 2. Distribusi responden berdasarkan Lama Kanker, Mekanisme Koping dan Kualitas Hidup Responden di RSUD Raden Mattaher Jambi tahun 2019

\begin{tabular}{clcc}
\hline No. & \multicolumn{1}{c}{ Yariabel } & Erekuensi (n) & Persentase (\%) \\
\hline $\mathbf{1}$ & Lama Kanker & 29 & 51,8 \\
& $<1$ tahun & 27 & 48,2 \\
\multirow{2}{*}{2} & $\geq 1$ tahun & & \\
& Mekanisme Koping & 31 & 55,35 \\
& Kurang baik & 25 & 44,65 \\
\multirow{2}{*}{3} & Baik & & \\
& Kualitas Hidup & 26 & 46,4 \\
& Kurang baik & 30 & 53,6 \\
\hline
\end{tabular}

Tabel 2 menunjukkan bahwa lama kanker untuk responden yang menderita kanker $<1$ tahun dan $>1$ tahun menunjukkan proporsi yang hampir sama besar. Hasil penelitian juga menunjukkan responden yang memiliki mekanisme koping baik sebanyak 25 orang $(44,65 \%)$ dari 56 responden, responden yang mempunyai kualitas hidup baik menunjukkan persentase yang lebih besar yaitu sebanyak 30 orang $(53,5 \%)$.

Jika dibandingkan dengan penelitian Nurhikmah, W (2008) tentang kualitas hidup dengan menggunakan Cancer Coping Questionnaire 21 dan WHOQoL-BREF maka hasil penelitian ini bisa dikatagorikan cukup baik. Young (2009) mengatakan kualitas hidup yang rendah bagi pasien dapat menyebabkan perubahan pada kemampuannya untuk melaksanakan fungsi kehidupannya sehari-hari dan membutuhkan peningkatan kompleksitas penanganan pasien.

Tabel 3. Kualitas Hidup Responden berdasarkan EORTC QLQ $30(\mathrm{n}=56)$

\begin{tabular}{|c|c|c|c|c|c|}
\hline No & Dimensi & Sngt Sering n (\%) & Cukup Sering n (\%) & Kadang-kadang $\mathrm{n}(\%)$ & Tidak Pernah n (\%) \\
\hline \multicolumn{6}{|c|}{ Skala Fungsional } \\
\hline \multirow[t]{6}{*}{1.} & Fisik & & & & \\
\hline & Kegiatan berat & $35(62,5)$ & $9(16,07)$ & $7(30,35)$ & $5(8,92)$ \\
\hline & Terbatas berjalan jauh & $30(53,57)$ & $10(17,85)$ & $8(14,28)$ & $8(14,28)$ \\
\hline & Terbatas berjalan dekat & $9(16,07)$ & $17(30,35)$ & $14(25)$ & $16(28,57)$ \\
\hline & Berbaring & $11(19,64)$ & $5(8,9)$ & $12(21,42)$ & $28(50 \%)$ \\
\hline & Bantuan orang lain & $7(12,5)$ & $6(10,71)$ & $11(19,64)$ & $32(57,14)$ \\
\hline \multirow[t]{3}{*}{2.} & Peran & & & & \\
\hline & Keterbatasan bekerja & $15(26,78)$ & $14(25)$ & $15(26,78)$ & $12(21,42)$ \\
\hline & Terbatas keg santai & $14(25)$ & $18(34,14)$ & $14(25)$ & $10(17,85)$ \\
\hline \multirow[t]{3}{*}{3.} & Kognitif & & & & \\
\hline & Sulit konsentrasi & $5(8,9)$ & $8(14,28)$ & $2(3,57)$ & $41(73,21)$ \\
\hline & Sulit mengingat & $4(7,1)$ & $3(5,4)$ & $11(19,64)$ & $38(67,85)$ \\
\hline \multirow[t]{5}{*}{4.} & Emosional & & & & \\
\hline & Tegang & $4(7,1)$ & $4(7,1)$ & $26(46,42)$ & $22(39,28)$ \\
\hline & Khawatir & $1(1,78)$ & $6(10,71)$ & $30(53,57)$ & $19(33,92)$ \\
\hline & Tersinggung & $5(8,9)$ & $3(5,4)$ & $17(30,35)$ & $31(55,35)$ \\
\hline & Emosi & $1(1,78)$ & $2(3,57)$ & $12(21,42)$ & $41(73,21)$ \\
\hline \multirow[t]{4}{*}{5} & Fungsi Sosial & & & & \\
\hline & Kehidupan keluarga & $1(1,78)$ & $3(5,4)$ & $10(17,85)$ & $42(75)$ \\
\hline & Aktivitas social & $4(7,1)$ & $6(10,71)$ & $8(14,28)$ & $38(67,85)$ \\
\hline & & & Skala Gejala & & \\
\hline \multirow[t]{5}{*}{6.} & Fatigue & & & & \\
\hline & Istirahat & $1(1,78)$ & $12(21,42)$ & $23(41,07)$ & $20(35,71)$ \\
\hline & Kelelahan & $13(23,21)$ & $17(30,35)$ & $18(32,14)$ & $8(14,28)$ \\
\hline & Badan Lemah & $14(25)$ & $18(34,14)$ & $14(25)$ & $7(12,5)$ \\
\hline & Sesak Nafas & $4(7.1)$ & $5(8,9)$ & $8(14,3)$ & $39(69,6)$ \\
\hline \multirow[t]{3}{*}{7.} & Nyeri & & & & \\
\hline & Merasa nyeri & $13(23,2)$ & $12(21,4)$ & $22(39,3)$ & $9(16,1)$ \\
\hline & Mengganggu aktivitas & $15(26,8)$ & $10(17,9)$ & $16(28,6)$ & $15(26,8)$ \\
\hline 8. & Nausea & $8(14,3)$ & $13(23,2)$ & $9(16,1)$ & $26(46,4)$ \\
\hline 9. & Muntah & $3(5,4)$ & $4(7,4)$ & $9(16,1)$ & $40(71,4)$ \\
\hline 9 & Nafsu makan menurun & $10(17,9)$ & $11(19,6)$ & $11(19,6)$ & $24(42,9)$ \\
\hline 10 & Konstipasi & $5(8,9)$ & $8(14,3)$ & $4(7,1)$ & $39(69,6)$ \\
\hline 11 & Diare & 0 & $5(8,9)$ & $4(7,1)$ & $47(83,9)$ \\
\hline 12 & Kesulitan tidur & $9(16,07)$ & $8(14,3)$ & $13(23,21)$ & $26(46,42)$ \\
\hline 13 & Kesulitan Finansial & 0 & $1(1,78)$ & $11(19,64)$ & $44(78,57)$ \\
\hline \multicolumn{6}{|c|}{ Kualitas Hidup keseluruhan } \\
\hline 1 & Kondisi Fisik & 0 & $11(19,64)$ & $32(57,14)$ & $13(23,21)$ \\
\hline 2 & Kualitas Hidup & 0 & $16(28,57)$ & $34(60,71)$ & $6(10,71)$ \\
\hline
\end{tabular}


Dari tabel 3 menunjukkan hasil bahwa dari dua komponen kualitas hidup , dari Skala Gejala diketahui bahwa gejala yang paling banyak dikeluhkan responden adalah nyeri yang menggangu aktivitas sebanyak 15 orang $(26,8 \%)$. Sedangkan untuk gejala yang tidak ada pada sebagian responden terbanyak pada gejala diare sebanyak 47 orang $(83,9 \%)$, Hasil penelitian ini tidak jauh berbeda dengan hasil penelitian yang dilakukan (Safaee, Moghimi-Dehkordi, Zeighami, Tabatabaee, \& Pourhoseingholi, 2008) bahwa gejala yang sering dikeluhkan pasien adalah insomnia, kelelahan dan rasa sakit.Gejala lainnya seperti diare, sembelit, sesak nafas, mual dan muntah dilaporkan kurang parah.

Sedangkan dari skala fungsional diketahui bahwa dari aspek fisik diketahui bahwa item kegiatan berat merupakan aspek yang paling sering dikeluhkan responden sebanyak 35 orang $(62,5 \%)$, sedangkan untuk aspek emosional, rata-rata responden berada pada skala kadang-kadang, paling banyak pada item khawatir sebanyak 30 orang $(53,57 \%)$. Untuk kualitas hidup keseluruhan responden penelitian sebagian besar masuk dalam skala sedang sebanyak 34 orang $(60,71)$. Kualitas hidup yang baik diperlukan untuk mendapatkan status kesehatan yang baik sehingga dapat mempertahankan sehingga dapat mempertahankan fungsi dan kemampuan fisik seoptimal mungkin dan selama mungkin, Bila kualitas hidup menurun,maka keinginan untuk sembuh juga turun (Sasmita, 2016)

\section{Analisis Bivariat}

Tabel 4. Hubungan Karakteristik Responden dengan Kualitas Hidup Responden di RSUD Raden Mattaher Jambi tahun 2019

\begin{tabular}{cccccccc}
\hline & \multicolumn{3}{c}{ Kualitas Hidur } & \multicolumn{2}{c}{ Total } & \multirow{2}{*}{ p-value } \\
\cline { 2 - 5 } & \multicolumn{2}{c}{ Kurang Baik } & \multicolumn{2}{c}{ Baik } & & \\
\cline { 2 - 6 } & $\mathrm{n}$ & $\%$ & $\mathrm{~N}$ & $\%$ & $\mathrm{~N}$ & $\%$ & \\
\hline Umur<45 tahun & 6 & 37,5 & 10 & 62,5 & 16 & 100 & 0,702 \\
Umur $\geq 45$ tahun & 19 & 42,6 & 21 & 57,4 & 40 & 100 & \\
Pendidikan Rendah & 20 & 43,5 & 26 & 56,5 & 53 & 100 & 0,769 \\
Pendidikan Tinggi & 5 & 50 & 5 & 50 & 47 & 100 & \\
Tidak Bekerja & 14 & 37,1 & 22 & 62,9 & 35 & 100 & 0,24 \\
Bekerja & 12 & 57,1 & 9 & 42,9 & 21 & 100 & \\
\hline
\end{tabular}

Hasil analisis bivariat antara umur dengan kualitas hidup diperoleh bahwa terdapat sebanyak 19 orang responden $(42,6 \%)$ yang memiliki usia $\geq 45$ tahun yang memiliki kualitas hidup kurang baik, sedangkan terdapat 10 orang responden $(62,5 \%)$ yang berusia $<45$ tahun yang memiliki kualitas hidup baik. Hasil uji statistik diperoleh nilai $\mathrm{p}$ value $=0,702$, maka dapat disimpulkan tidak ada hubungan yang signifikan antara usia dengan kualitas hidup. Menurut peneliti, tidak berhubungannya veriabel usia dengan kualitas hidup dikarenakan semakin tinggi usia seseorang berkaitan dengan proses kedewasaan, kematangan emosi seseorang dan penerimaan seseorang dalam menerima sesuatu hal yang tidak nyaman bagi dirinya, sehingga dalam hal ini, responden yang $\geq 45$ tahun mempunyai proporsi yang lebih baik baik dalam hal kualitas hidupnya

Hasil analisis bivariat antara tingkat pendidikan dengan kualitas hidup diperoleh bahwa hanya proporsi $50 \%$ responden yang berpendidikan tinggi memiliki kualitas hidup baik. Hasil uji statistik diperoleh nilai $\mathrm{p}$ value $=0,769$, maka dapat disimpulkan tidak ada hubungan yang signifikan antara tingkat pendidikan dengan kualitas hidup. Hasil penelitian ini sejalan dengan penelitian Trisetyaningsih (2015) yang mengatakan tingkat pendidikan tidak memiliki hubungan bermakna dengan kualitas hidup pasien kanker payudara.

Pendidikan masyarakat yang rendah akan beresiko 1,2 kali mempunyai kualitas hidup yang kurang baik dibandingkan dengan berpendidikan tinggi. Tingkat pendidikan mempengaruhi pola pikir seseorang, semakin tinggi tingkat pendidikan seseorang maka akan berpikir panjang dalam usaha mencari pengobatan dirinya (Muttaqin, 2008).

Hasil analisis bivariat antara pekerjaan dengan kualitas hidup diperoleh bahwa terdapat sebanyak 9 responden $(42,9 \%)$ responden yang bekerja memiliki kualitas hidup baik. Hasil uji statistik diperoleh nilai $\mathrm{p}$ value $=0,238$, maka dapat disimpulkan tidak ada hubungan yang signifikan antara pekerjaan dengan kualitas hidup. Hasil penelitian ini tidak sesuai dengan penelitian (Safaee et al., 2008) yang mengatakan bahwa pekerjaan berhubungan dengan kualitas hidup pasien.

Tabel 5. Distribusi Responden berdasarkan Variabel Lama Kanker dan Kualitas Hidup di RSUD Raden Mattaher Jambi tahun 2019

\begin{tabular}{ccccccc}
\hline Lama & \multicolumn{4}{c}{ Kualitas Hidup } & Total & \multirow{2}{*}{ p-value } \\
\cline { 2 - 5 } Kanker & \multicolumn{2}{c}{ Kurang Baik } & \multicolumn{2}{c}{ Baik } & & \\
\cline { 2 - 5 } & $\mathrm{n}$ & $\%$ & $\mathrm{~N}$ & $\%$ & $\mathrm{~N}$ & \\
\hline$<$ 1tahun & 19 & 65,5 & 10 & 34,5 & 19 & \\
$>1$ tahun & 7 & 25,9 & 20 & 74,1 & 21 & \multirow{2}{*}{0,007} \\
Jumlah & 25 & 46,4 & 31 & 53,6 & 56 & \\
\hline
\end{tabular}

Hasil analisis bivariat antara lama dengan kualitas hidup diperoleh bahwa proporsi responden yang menderita kanker $<1$ tahun yang berkualitas hidup baik lebih besar dari yang menderita kanker $\geq 1$ tahun. Hasil uji statistik diperoleh nilai $\mathrm{p}$ value $=0,007$, maka dapat disimpulkan ada hubungan yang signifikan antara lama kanker dengan kualitas hidup.

Hasil penelitian ini sesuai dengan penelitian Nurhikmah W (2018) yang menyatakan ada hubungan bermakna antara lama menderita kanker dengan kualitas hidup pasien kanker payudara di RS Kabupaten Semarang dengan nilai $p$ value 0,048 .

Setiap penyakit fisik yang dialami seseorang tidak hanya membawa masalah fisik, tetapi juga membawa masalah psikologis. Hal ini dapat terlihat pada pasien kanker payudara, ketika dokter mendiagnosisnya bahwa dia menderita penyakit berbahaya, maka akan timbul 
masalah emosional. (Sinuraya, E 2017). Menurut peneliti, responden yang belum lama menderita penyakit kanker maka respon emosional yang muncul biasanya penolakan, kcemasan, denial dan depresi. Respon tersebut bila tidak teratasi dengan baik maka berkaitan langsung dengan kualitas hidup. Dimana pasien yang sudah mampu menerima kondisi dirinya maka dia akan lebih dapat melakukan proses penerimaan dan adaptasi terhadap penyakitnya, sehingga kualitas hidupnya cenderung membaik.

Tabel 6. Distribusi Responden berdasarkan Variabel Mekanisme Koping dan Kualitas Hidup di RSUD Raden Mattaher Jambi Tahun 2019

\begin{tabular}{cccccccc}
\hline & \multicolumn{4}{c}{ Kualitas Hidup } & \multirow{2}{*}{ Total } & \multirow{2}{*}{ p-value } \\
\cline { 2 - 6 } Mekanisme Koping & Kurang Baik & \multicolumn{3}{c}{ Baik } & & & \\
\cline { 2 - 7 } & $\mathrm{n}$ & $\%$ & $\mathrm{~N}$ & $\%$ & $\mathrm{~N}$ & $\%$ & \\
\hline Kurang Baik & 19 & 66 & 12 & 38,7 & 31 & 100 & \\
Baik & 7 & 21,3 & 18 & 72 & 25 & 100 & 0,027 \\
Jumlah & 26 & 46,6 & 30 & 53,6 & 100 & 100 & \\
\hline
\end{tabular}

Hasil analisis bivariat antara mekanisme koping dengan kualitas hidup diperoleh bahwa terdapat sebanyak 12 orang responden yang memiliki mekanisme koping yang kurang baik, memiliki kualitas hidup yang baik. Hasil uji statistik diperoleh nilai $\mathrm{p}$ value $=0,027$ maka dapat disimpulkan ada hubungan yang signifikan antara mekanisme koping dengan kualitas hidup.

Hal ini sesuai dengan penelitan Nurhikmah W (2018) yang menyatakan ada hubungan mekanisme koping dengan kualitas hidup dengan $\mathrm{p}$ value 0,048 . .Hasil penelitian juga menunjukkan bahwa proporsi responden dengan mekanisme koping maladaftif sebagian besar berkualitas hidup baik sebanyak 21 orang $(58,3 \%)$.

Mekanisme koping adalah usaha individu untuk mengatasi perubahan yang dihadapi atau beban yang diterima tubuh dan beban tersebut menimbulkan respon tubuh yang sifatnya non spesifik yaitu stress (Hawari D, 2015). Mekanisme koping maladaftif merupakan adalah mekanisme yang menghambat fungsi integrasi, menurunkan otonomi dan cenderung menguasai lingkungan.

Penderita kanker payudara yang mampu menghadapi dan bangkit dari keterpurukan yang dialami akan mendorongnya untuk memiliki kualitas hidup yang berkualitas, sebaliknya respon negative dari seseorang penderita kanker membuat kualitas hidupnya memburuk (Sinuraya, E, 2017).

Hae-Chung Y (2008) berpendapat apabila strategi koping yang digunakan sesuai dapat mempengaruhi emosi bahkan pikiran seseorang sehingga dapat mengurangi stresor yang dihadapi. Strategi ini dapat menghasilkan kualitas hidup yang lebih baik dan menghasilkan tindakan yang positif..

Untuk itu diharapkan peran penting perawat kemoterapi dalam menunjang kesembuhan pasien sangat dibutuhkan sekali yaitu dengan memberikan asuhan keperawatan secara komprehensif baik secara bio, psiko, sosial dan spritual.

\section{SIMPULAN}

1. Karakteristik demografi responden yaitu rata-rata usia responden adalah 51,8 tahun, mayoritas berpendidikan SD dan SMA dengan proporsi $35,7 \%$, dan sebagian besar tidak bekerja sebanyak 35 orang $(62,5 \%)$.

2. Tidak terdapat hubungan antara karakteristik demografi dengan kualitas hidup pasien kanker payudara di RSUD Raden Mattaher Jambi

3. Terdapat hubungan antara lama kanker dengan kualitas hidup pasien kanker payudara di RSUD Raden Mattaher Jambi

4. Terdapat hubungan antara mekanisme koping dengan kualitas hidup pasien kanker payudara di RSUD Raden Mattaher Jambi

\section{DAFTAR PUSTAKA}

Anggorowati, L. (2013). Faktor Resiko Kanker Payudara wanita. Jurnal Kesehatan Masyarakat, 8(2). https://doi.org/https://dor.org/10.15294/kemas v8i2.2635

Angraini D, dkk. (2018). Faktor-faktor yang Mempengaruhi Kualitas Hidup Penderita Kanker Payudara di Kota Padang. Jurnal Endurance.

Bayram, Z., Durna, Z., \& Akin, S. (2014). Quality of life during chemotherapy and satisfaction with nursing care in Turkish breast cancer patients. European Journal of Cancer Care, 23(5), 675-684. https://doi.org/10.1111/ecc.12185

Hae-chung, Y. (2008). Stress and Quality of Life in Breast Cancer Recurrence: Mediation of coping. Annals of Behavioral Medicine, 35(2).

Hawari, D (2015). Manajemen Stress Cemas dan Depresi. Edisi 2. Jakarta : Balai Penerbit FKUI

Infodatin. 2016. Pusat Data dan Informasi Kementrian Kesehatan RI. Jakarta

International Agency for Research on Cancer (2018). Cancer Breast. Diakses tanggal 6 April 2019 dari https://gco.iarc.fr/today/data/factsheets/cancers/20 -Breast-fact-sheet.pdf

Johansson et al. (2013). The relationship among coping strategies, religious coping and spirituality in African American women with breast cancer receiving chemotherapy.

Kamelia, 2013. Konsep Diri pada Wanita Penderita Kanker Payudara (Carcinoma Mammae). Skripsi-Program Studi Psikologi Fakultas Dakwah Institut Agama

Muttaqin (2008). Seri Asuhan Keperawatan Klien dengan Penyakit Kronis. Jakarta. Salemba Medika

Nurhikmah W (2018). Hubungan Mekanisme Koping dengan Kualitas Hidup pada Pasien Kanker 
Payudara. Jurnal Imu Keperawatan Jiwa Volume 1. PPNI Jawa Tengah

Purkayastha, S. and. (2017). Factors affecting Quality of life in breast cancer patients, a descriptive and cross-sectional study review of literature. $J$ Midlife Health, 8(2), 75-83.

RSUD Raden Mattaher, 2019. Data pasien kanker payudara tahun 2017-2018.

Safaee, A., Moghimi-Dehkordi, B., Zeighami, B., Tabatabaee, H. R., \& Pourhoseingholi, M. A. (2008). Predictors of quality of life in breast cancer patients under chemotherapy. Indian Journal of Cancer, 45(3), 107-111. https://doi.org/10.4103/0019-509X.44066

Sasmita (2016). Faktor yang Mempengaruhi Kualitas Hidup Pasien Kanker Payudara di RSUP M.Jamil Padang. Thesis. Universitas Andalas

Sinuraya, E. (2017). Kualitas Hidup Penderita Kanker Payudara di Poli Onkologi RSU dr.Pringadi Medan.

Stuart, W. G. (2013). Principles and Practice of Psychiatric Nursing (10th ed.). St,Louis Missouri: Elsevier Mosby.

Trisetyaningsih, Yanita (2015). Faktor-faktor yang Berhubungan dengan Kualitas Hidup PerempuanKlimaterik.http://e journal. Stikesayanik.ac.id/index/Php/Milk/article/view/4) 